\title{
Reconstruction of light environment for Pennsylvanian marattialean ferns: Insights from FTIR analysis of living Cyathea caracasana
}

\author{
ERWIN L. ZODROW \& MARIA MASTALERZ
}

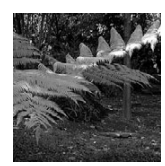

\begin{abstract}
Fourier transform infrared spectroscopy (FTIR), a nondestructive test, has been successfully applied as an investigative technique to Carboniferous-age seed ferns, and some true ferns, but not to living ferns. In this study, we applied the technique to the tree fern Cyathea caracasana that grows in bright sunlight in the Andean mountains to primarily test applicability to a living fern. The secondary purpose concerns accumulating phytochemical parameters for a comparative study of Carboniferous palaeocological counterparts. The study sample comprises two oven-dried ultimate pinnae that are subdivided into five sample sets, designed to represent sterile pinnate tips, fertile basal pinnule portions, empty sporangia enveloped in indusia removed from the latter, and the ultimate pinna rachis. Two additional sample sets were used for spectral quality control. We document that FTIR furnished quality spectra suitable for the interpretation of phytochemical calculations from these sample sets. Moreover, based on the absorbance spectra, we were able to reduce the five sample sets to three related-chemical groups. The reduction is principally based on aliphatic (carbon-atom joined open chain structures) and oxygen-containing moieties, but factoring into the related chemical groups the cellulose, mirroring, although not perfectly, predominating organ tissue in the subdivision of the sample sets. In effect, we have isolated the main chemical parameters for the foliage and sporangia (excluding spores) of $C$. caracasana. - Key words: FTIR, extant fern, Cyatheaceae, sun leaves, phytochemistry.
\end{abstract}

ZODROW, E.L. \& MASTALERZ, M. 2010. Reconstruction of light environment for Pennsylvanian marattialean ferns: Insights from FTIR analysis of living Cyathea caracasana. Bulletin of Geosciences 85(2), 361-365 (2 figures, 2 tables). Czech Geological Survey, Prague. ISSN 1214-1119. Manuscript received March 31, 2010; accepted in revised form June 8, 2010; published online June 24, 2010; issued June 30, 2010.

Erwin L. Zodrow (corresponding author), Palaeobotanical Laboratory, Cape Breton University, Sydney, Nova Scotia, Canada B1P 6L2; Erwin_Zodrow@cbu.ca • Maria Mastalerz, Indiana Geological Survey, Indiana University, Bloomington, IN, 47405 USA; mmastale@indiana.edu

We have been testing the feasibility of applying the FTIR technique to fertile foliage of extant ferns that includes Marattia sp. and Cyathea caracasana (Klotzsch) Domin (Tryon 1976), families Marattiaceae and Cyatheaceae, respectively. Of these two, we have chosen the latter living species, a 2 m to $6 \mathrm{~m}$ tall Andean tree fern. Arens (1997, 2001) investigated this fern species in respect to responses of leaf anatomy to light environment (sun leaves), and plant performance as a function of successional habit, respectively. In her 1997 paper, Arens made the poignant suggestion that the sun leaves of $C$. caracasana represent a living model for certain Pennsylvanian-age medullosalean tree-ferns, i.e., certain pteridosperm species of Alethopteris Sternberg, 1825, Neuropteris (Brongniart) Sternberg, 1825, Macroneuropteris (Hoffmann) Cleal, Shute \& Zodrow, 1990, and Laveineopteris Cleal, Shute \& Zodrow, 1990. This assessment is based predominantly, but not exclusively, on a shared leaf anatomy and morphology (see
Arens 1997, table 4). In this paper, we present FTIR data from that Andean tree fern to document its phytochemical, and also elemental chemical data, i.e., carbon, nitrogen, hydrogen, sulfur, and oxygen (by calculation) contents for future comparison in our on-going series of experimental studies with living plants.

\section{Materials}

The pinnate material analyzed in this study originated from an in situ tree fern that was growing in full sun at $1800 \mathrm{~m}$

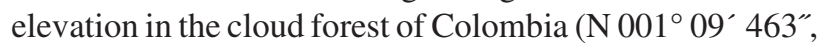
$\mathrm{W} 077^{\circ} 58^{\prime} 590^{\prime \prime}$ ). It was collected and identified by Prof. Nan C. Arens in 1994 as C. caracasana (Arens 1997). The sample represents oven-dried material of two fragmentary, fertile ultimate pinnae, $3-\mathrm{cm}$ and a $1.7-\mathrm{cm}$ long, respectively (Fig. 1A, B), using the terminology of 


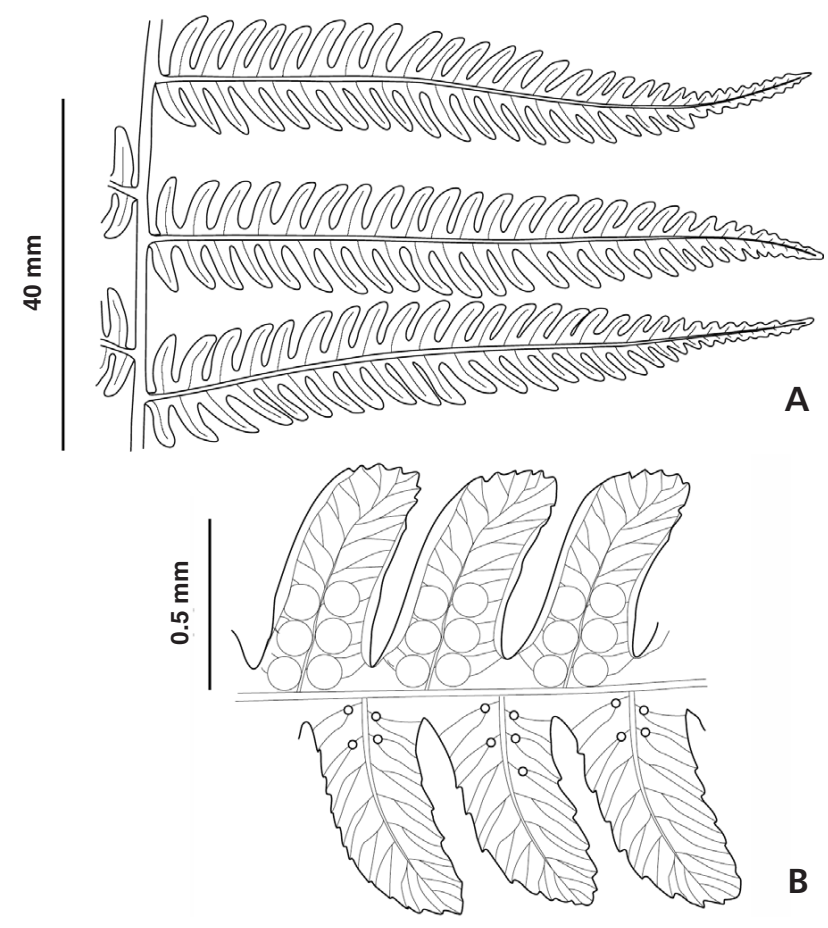

Figure 1. Cyathea caracasana, Andes Mountains, fertile pinnate parts. - A - three complete ultimate pinnae with slender, sterile terminal parts. - B - fertile pinnules, where sporangia (circles) are confined to the basal part of the pinnule. Redrawn from Tryon (1976, figs 129, 130).

Carboniferous-frond architecture (e.g., Zodrow \& Cleal 1988, text-fig. 2). The 3-cm long ultimate pinna was subdivided into five sample sets (Table 1), based on tissue differences. For the sample preparation this means that the rachis of the ultimate pinna was separated from its leaf lamina, e.g., Zodrow \& Mastalerz (summary, 2007, p. 317), and that fructification structure was removed from the lamina prior to analysis. The resulting set 1 represents the sterile, 1-cm long terminal pinnule seen in Fig. 1A; set 2 the sterile upper $c a$ one-half portion of each of the three contiguous pinnules (= apical pinnules); set 3 the lower fertile one-half portion of the three contiguous pinnules (= basal pinnules); set 4 the rachis to which the three pinnules are attached; and set 5 represents the empty sporangia and indusia. Microscopic observation unequivocally established dehisced, empty sporangia, but separating them from the indusia proved impracticable. The remaining two sets 6 and 7 (Table 1) represent random ultimate pinnule fragments of the 1.7-cm long ultimate pinna that are analyzed for spectral quality control.

\section{Methods}

Infrared (IR) spectroscopy registers changes in dipole moments which result from bond vibrations caused by absorption of the IR radiation, allowing the identification of functional groups in organic substances (and in certain minerals, see Zodrow et al. 2010). However, not all bonds in a structure of a biomolecule respond vibrationally, and this is where Raman IR spectroscopy represents a complementary approach (Smith 1996), though rarely, if ever, used in this context. We emphasize the economical advantage of low-cost FTIR analysis, coupled with minimal sample requirement of less than $0.5 \mathrm{mg}$ for quality spectra, and the nondestructive nature of the sample methods that allow unrestrictive FTIR reuse.

FTIR spectra show differences in functional-group abundances, even when spectra appear similar in terms of peak shape, peak positions, and intensities. However, closer analysis of the spectral files can reveal subtle differences that can be important for the interpretation of chemical structure. This involves the calculation of ratios of integrated areas under the IR-absorbance bands for semi-quantitative analysis. Two ratios are commonly used and important here. One is the methylene/methyl ratio $\left(\mathrm{CH}_{2} / \mathrm{CH}_{3}\right)$ that relates to the aliphatic-chain length of hydrocarbons and to the degree of branching of aliphatic side chains attached to the biomolecular structure. The ratio is calculated after deconvoluting the aliphatic stretching region (2800-3000 $\mathrm{cm}^{-1}$ ) into individual peaks. A larger ratio implies comparatively longer and straight chains, and a smaller one shorter and more branched chains (Mastalerz \& Bustin 1993; Lis et al. 2005; D'Angelo 2006; Lin \& Ritz $1993 \mathrm{a}, \mathrm{b})$. The other ratio is that of integrated areas of aliphatic C-H stretching vibrations at $3000-2800 \mathrm{~cm}^{-1}$ to those of $1800-1600 \mathrm{~cm}^{-1}$ oxygen-containing compounds $(\mathrm{Al} / \mathrm{Ox})$. No spectral manipulation is performed in this region, as areas under the peaks are measured directly. This ratio provides information about the degree of oxidation of the organic matter (Pradier et al. 1992, Mastalerz \& Bustin 1997). From a larger ratio comparatively decreasing oxygen-containing moieties can be inferred, i.e., the lower the ratio, the higher the content of the oxygenated group-Ox. However, other ratios are also used, depending on the purpose for interpretation (Zodrow et al. 2009).

We used the well-established KBr-pellet method (see Mastalerz \& Bustin 1995), where between 0.9 to $1.8 \mathrm{mg}$ of the sample was ground with $\mathrm{ca} 250 \mathrm{mg}$ of crystalline $\mathrm{KBr}$ to make a pellet through which an IR-laser beam was passed. 256 scans per samples were collected at a resolution of $4 \mathrm{~cm}^{-1}$ wavenumber to produce an IR spectrum, using a Nicolet 6700 FT-IR instrument equipped with DTGS detector. As the dried foliage is rather thick, repeat FTIR analyses were performed to check for consistency of IR results.

Elemental analysis was performed on a Carlo Erba 1108 CHNS-O Elemental Analyzer. Sample amount for the combined apical and basal pinnules (= entire pinnule) were $3.5 \mathrm{mg}$, for the pinna rachis $1.4 \mathrm{mg}$, and for the sporangial and indusial material $2 \mathrm{mg}$. 
Erwin L. Zodrow \& Maria Mastalerz • Reconstruction of light environment for Pennsylvanian marattialean ferns

Table 1. IR-derived semi-quantitative chemical ratios $\mathrm{CH}_{2} / \mathrm{CH}_{3}$ and $\mathrm{Al} / \mathrm{Ox}$ of the fertile ultimate pinnae of Cyathea caracasana. Sample sets 1 to 7.

\begin{tabular}{|c|c|c|c|c|c|}
\hline Set/Pinnate part & $\begin{array}{c}\text { Sample } \\
\text { weight mg }\end{array}$ & Description/Sampling remarks & Group 1 to & $\mathrm{CH}_{2} / \mathrm{CH}_{3}$ & $\mathrm{Al} / \mathrm{Ox}$ \\
\hline \multicolumn{6}{|l|}{ 3-cm long pinna } \\
\hline Set 1. Pinna tip & 1.0 & 1-cm long, $1 \mathrm{~mm}$ wide terminating tip of ultimate pinna; sterile & 1 & 2.90 & 0.22 \\
\hline \multirow[t]{2}{*}{ Set 2. Apical pinnules (3) } & 1.3 & $\begin{array}{l}\text { The sterile upper } c a \text { one half portion of each of the three contiguous } \\
\text { pinnules }\end{array}$ & 1 & 2.89 & 0.23 \\
\hline & & Reground pellet & & 2.83 & 0.25 \\
\hline \multirow[t]{2}{*}{ Set 3. Basal pinnules (3) } & 0.9 & $\begin{array}{l}\text { The lower one half portion of the three contiguous pinnules; sporangia, } \\
\text { indusia, and pinnule rachis removed }\end{array}$ & 2 & 4.37 & 0.01 \\
\hline & & Reground pellet & & 4.30 & 0.01 \\
\hline \multirow[t]{2}{*}{ Set 4. Ultimate pinna rachis } & 0.9 & Axis to which the (3) pinnules are attached & 2 & 2.90 & 0.02 \\
\hline & & Reground pellet & & 2.39 & 0.03 \\
\hline \multirow[t]{2}{*}{ Set 5. Sporangia } & 1.8 & Sporangial walls mixed with indusia & 3 & 2.66 & 0.55 \\
\hline & & Reground pellet & & 2.94 & 0.73 \\
\hline \multicolumn{6}{|l|}{ 1.7-cm long pinna } \\
\hline Set 6. Random apical pinnules & 1.4 & $\begin{array}{l}\text { Three apical pinnule portions, } c \text { a } 3 \text {-mm maximum length; sporangia } \\
\text { and indusia removed }\end{array}$ & & 2.82 & 0.22 \\
\hline Set 7. Random pinnule fragments & 0.8 & Seven pinnule fragments; sporangia and indusia, and axis removed & & 3.31 & 0.20 \\
\hline
\end{tabular}

\section{Results}

Individual FTIR spectra of the five sets of the 3-cm long ultimate pinna are presented in Fig. 2. Analyzing the constituent spectra quantitatively, three chemical groups are recognized.

Group 1 comprises sets 1 and 2 (pinna tip, and three contiguous apical pinnules, Fig. 2A, B, respectively). These spectra are characterized by moderate aliphatics in the aliphatic stretching $\left(2800-3000 \mathrm{~cm}^{-1}\right)$ and bending regions (peaks at 1446 and $1375 \mathrm{~cm}^{-1}$ ). Distinct oxygenated groups are represented by peaks $\sim 1730 \mathrm{~cm}^{-1}$ and $\sim 1630 \mathrm{~cm}^{-1}$, assigned to esters and conjugated ketones, respectively (Pradier et al. 1992). A peak at $\sim 1517 \mathrm{~cm}^{-1}$ likely represents a benzene ring. Additional distinct bands include those at $1288 \mathrm{~cm}^{-1}$, interpreted as $\mathrm{CH}_{2}-\mathrm{O}-\mathrm{H}$ deformation in cellulose, and a broad band at $1063 \mathrm{~cm}^{-1}$ interpreted as C-OH deformation in cellulose (Blackwell 1977). In the last band, it is possible that there is some contribution from the clay mineral kaolinite, or other mineral.

Group 2 is represented by sets 3 and 4 (three contiguous basal pinnule portions, and the pinnule rachis, Fig. 2C, D, respectively). These spectra have surprisingly very few functional groups, and in addition to hydroxyl at $3432 \mathrm{~cm}^{-1}$, there is only one prominent band at $1634 \mathrm{~cm}^{-1}$, assigned to highly conjugated $\mathrm{C}=\mathrm{O}$ (ketones) in lignin. Aliphatic hydrogen is non-detectable.

Group 3 is represented by set 5 alone (sporangia and indusia), with its spectrum (Fig. 2E) showing strong aliphatic stretching bands in the $2800-3000 \mathrm{~cm}^{-1}$ region, strong oxygenated groups with peaks at $1736 \mathrm{~cm}^{-1}$ (esters), and at $1637 \mathrm{~cm}^{-1}$ (conjugated ketones), and less distinct peaks at $1517 \mathrm{~cm}^{-1}$ (benzene rings), $1446 \mathrm{~cm}^{-1}$ $\left(\mathrm{CH}_{2}, \mathrm{CH}_{3}\right.$ in bending mode), and at $1042 \mathrm{~cm}^{-1}$ (kaolinite). A band at $1275 \mathrm{~cm}^{-1}$ likely represents cellulose or hemicellulose.

These observations are supported by the FTIR-derived ratios of semi-quantitative chemistry (Table 1). Set 5 (sporangia and indusia) have the largest Al/Ox ratio, or comparatively low oxygen-containing moieties, whereas sets $1,2,3$, and 4 show comparatively higher oxygen moieties. $\mathrm{CH}_{2} / \mathrm{CH}_{3}$ ratios are similar (between 2.7 to 2.9 ) in sets 1,2 , and 5. For group 2 (sets 3 and 4), though the ratio is higher in set 3 . than in the other two groups, the value calculated for the ratios in these two sets may not be reliable because of the very small bands in the aliphatic stretching regions (see Zodrow \& Mastalerz 2007).

Elemental analyses are listed in Table 2, showing first of all no detectable sulfur. In various elemental combinations, however, the foliar tissues are separable and distinct from one another. For example, the set of dehisced sporangia and indusia shows comparatively the highest carbon, lowest oxygen, highest hydrogen, and an intermediate level of nitrogen, whereas the pinnule lamina shows intermediate levels of carbon, hydrogen, oxygen, but the highest level of nitrogen. However, the elementary data cannot be properly interpreted as the exact biopolymeric structure remains to be established (see Zodrow et al. 2009). 

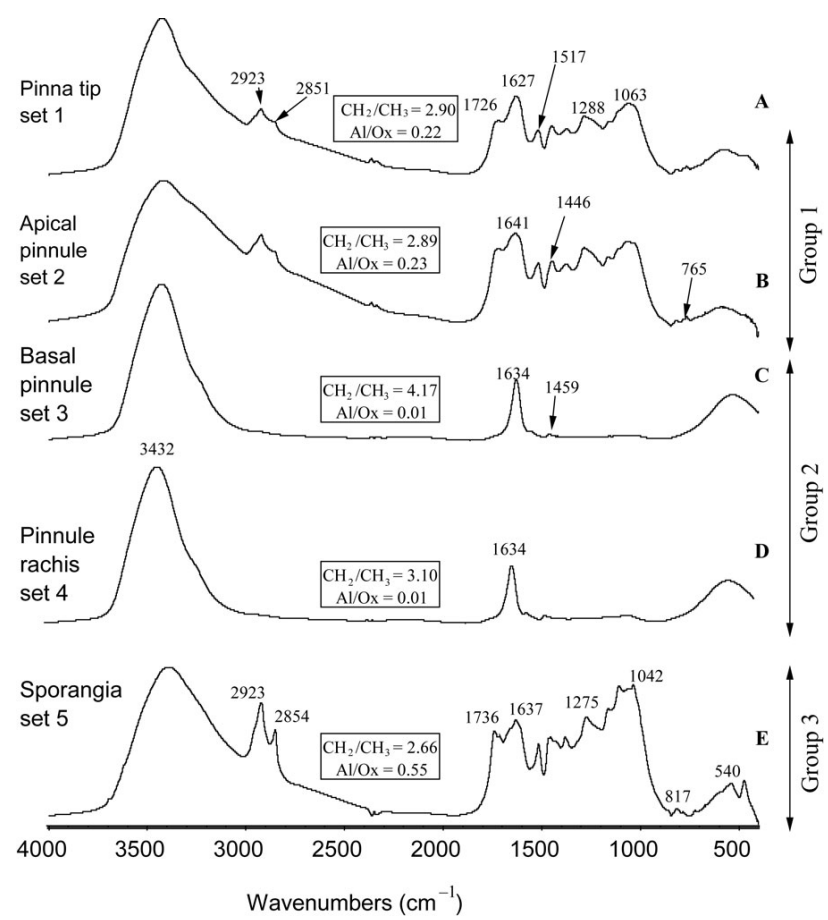

Figure 2. FTIR spectra of Cyathea caracasana. - A - sterile pinna tip. - B - apical part of pinnules. $\bullet \mathrm{C}$ - basal part of B. $\bullet \mathrm{D}$ - rachis to which the pinnules are attached. $\bullet \mathrm{E}-$ empty spore cases mixed with indusia.

In summary, congruency of functional-group chemistry is evident within group 1 , less so in group 2, but differences exist amongst the three groups, as presupposed in the sampling design for the 5 sets. For example, the great similarity of the ratios within group 1 reflects predominance of leaf lamina (very minor pinnule rachis) of homologous sterile apical pinnule and the sterile apical pinna tip (Heggie \& Zodrow 1994). This contrasts with group 3 and its reproductive-related tissue, not involving mother lamina and excluding spores, where the ratios differ in respect to group 1, though some uncertainty about reliability of group 3 ratios exists. Group 2 (sets 3 and 4) shows heterogenic chemistry as expressed in the ratios, where set 4 (rachis) is characterized by shorter and more branched aliphatic chains, but lower content of oxygenated groups. This is relative to set 3 and the lamina on which the reproductive organs grew and which shows a comparatively thick basal mid-vein portion as extension of the pinna rachis into the pinnule that extends to the pinnule apex, tapering in its course (Fig. 1B). Alternatively, group 3 could be split into two separate groups to more sharply distinguish between pinnate tissues.

\section{Concluding remarks}

The cellulose peaks in group 1 are likely explained by increased palisade-parenchyma tissue whose thin cell walls
Table 2. Elemental chemical analysis (weight percent) of sets 1, 2, 4 , and 5 of Cyathea caracasana.

\begin{tabular}{lccc}
\hline Element & $\begin{array}{c}\text { Sets 1 and 2 or } \\
\text { pinnule }\end{array}$ & $\begin{array}{c}\text { Set 4 Ultimate } \\
\text { rachis }\end{array}$ & $\begin{array}{c}\text { Set 5 Sporangia \& } \\
\text { indusia }\end{array}$ \\
\hline Carbon & 48.50 & 47.93 & 50.50 \\
\hline Oxygen & 44.22 & 45.03 & 41.56 \\
\hline Hydrogen & 5.35 & 5.61 & 6.33 \\
\hline Nitrogen & 1.93 & 1.43 & 1.61 \\
\hline Sulfur & nd & nd & nd
\end{tabular}

Averages of two or three analyses. Oxygen by subtraction from 100 . nd - not detected.

are known to contain mostly cellulose that characterizes sun-leaves, in contrast with shade-leaves where there is less cellulose (Arens 1997, Table 1). That raises the question if the cellulose band in the spectrum of the sporangia-indusia relates to parenchyma cells, to chloroplasts, or both? It is known that lignin serves the function of physical support for axes (see Solomon et al. 2005), and indeed a distinct band at $1634 \mathrm{~cm}^{-1}$ confirms the presence of lignin in group 2 . As expected, chemical differences between the ultimate-pinna rachis and lamina are evident in the $C$. caracasana data, based on differences in tissue composition. Moreover, based on our data fertile pinnules in C. caracasana can be differentiated from sterile ones by the absence of cellulose or hemicellulose moieties. If confirmed, we suggest this as a parameter in addition to the morphological evidence to distinguish between fertile and sterile fern foliage in the fossil record, given favorable diagenetic conditions.

It would be instructive to compare FTIR data between C. caracasana and the Carboniferous fern species Pecopteris unita Brongniart, 1836 (see Zodrow \& Mastalerz 2001), noting that their frond architecture are similar, though reproductive organs are dissimilar. The reasoning behind the comparison relates to the assumption that the Carboniferous ferns arguably were growing in fairly open, unshady habitats, as the wetlands were dominated by arborescent lycophytes that lacked a crown during most of their life (pers. comm. C.J. Cleal, July 7, 2009). Therefore, we believe these pecopteroids may have sun-leaf characteristics (Barthel 1962, Pšenička et al. 2005).

In summary, we have demonstrated that FTIR spectra obtained from oven-dried foliage of an extant tree fern show promise for a comparative analysis with Pennsylvanian-age counterparts. Although more research needs to be done to test the extent of applicability of this analysis, this study has also produced a set of elemental chemical data for which we have no comparative Carboniferous fern data, though we have elemental data for certain Carboniferous medullosaleans (Zodrow et al. 2009, table 7), which we feel are inappropriate for comparison at this juncture. 


\section{Acknowledgements}

N.C. Arens, Department of Geoscience, Hobart and William Smith Colleges, Geneva, NY, supplied the specimens of C. caracasana, C.J. Cleal, Department of Biodiversity and Systematic Biology, National Museums and Galleries of Wales, helped clarify for us sun leaves, the Indiana Geological Survey funded the elemental analysis, D. Keefe, Molecular Spectroscopy Research Laboratory, Cape Breton University, provided support for the FTIR analyses, and J. Pšenička, West Bohemian Museum, produced the art work in figure 1 . We are grateful for their efforts and continuing support. We thank the reviewers, C.J. Cleal, Museum Wales, UK, and J.A. D'Angelo, Universidad Nacional de Cujo, Argentina, for helpful suggestions to improve the quality of the MS.

\section{References}

ARENS, N.C. 1997. Responses of leaf anatomy to light environment in the tree fern Cyathea caracasana (Cyatheaceae) and its application to some ancient seed ferns. Palaios 1, 84-94. DOI $10.2307 / 3515296$

ARENS, N.C. 2001. Variation in performance of the tree fern Cyathea caracasana (Cyatheaceae) across a successional mosaic in the Andean cloud forest. American Journal of Botany 88(3), 545-551. DOI 10.2307/2657118

BARTHEL, M. 1962. Epidermisuntersuchungen an einingen inkohlten Pteridospermenblättern des Oberkarbons und Perms. Geologisches Beiheft 11, 1-140.

BLACKWELL, J. 1977. Infrared and Raman spectroscopy of cellulose, 206-221. In ARTHUR, J.C. JR. (ed.) Cellulose Chemistry and Technology. ACS Symposium Series 48, Washington, DC.

BRONGNIART, A. 1828-1837. Histoire des végétaux fossiles, ou recherches botanique et géologiques sur les végétaux renfermés dans les diverses couches du globe. 1- 488 pp., 2 72 pp. Fortin, Masson et Cie \& Crochard et Cie, Paris.

Cleal, C.J., Shute, C.H. \& ZodRow, E.L. 1990. A revised taxonomy for Palaeozoic neuropterid foliage. Taxon 39(3), 486-492. DOI 10.2307/1223109

D'ANGELO, J.A. 2006. Analysis by Fourier transform infrared spectroscopy of Johnstonia (Corystospermales, Corystospermaceae) cuticles and compressions from the Triassic of $\mathrm{Ca}-$ cheuta, Mendoza, Argentina. Ameghiniana 43(4), 669-685.

HegGIE, M. \& ZodROW, E.L. 1994. Fractal lobatobterid frond (Upper Carboniferous marattialean tree fern). Palaeontographica, Abteilung B 232, 35-57.

LIN, R. \& RITZ, G.P. 1993. Studying individual macerals using i.r. microspectroscopy, and implications on oil versus gas/condensate proneness and "low-rank" generation. Organic Geochemistry 20, 695-706. DOI 10.1016/0146-6380(93)90055-G

Lis, G.P., MASTALERZ, M., SCHIMMELMANN, N.A., LEWAN, M. \& STANKIEWICZ, B.A. 2005. FTIR absorption indices for thermal maturity in comparison with vitrinite reflectance Ro in type-II kerogen from Devonian black shales. Organic Geochemistry 36, 1533-1552. DOI 10.1016/j.orggeochem.2005.07.001

MASTALERZ, M. \& BUSTIN, R.M. 1993. Variation in maceral chemistry within and between coals of varying rank: an elec- tron microprobe and micro-FTIR investigation. Journal of Microscopy $171,153-166$.

MASTAlerZ, M. \& BuSTin, R.M. 1995. Application of reflectance micro-Fourier transform infrared spectrometry in studying coal macerals: comparison with other Fourier transform infrared techniques. Fuel 74, 536-542.

DOI 10.1016/0016-2361(95)98356-J

MASTALERZ, M. \& BUSTIN, R.M. 1997. Variation in chemistry of macerals in coals of the Mist Mountain Formation, Elk Valley Coalfield, B.C., Canada. International Journal of Coal Geology 33, 43-59. DOI 10.1016/S0166-5162(96)00003-1

PRADIER, B., LANDAIS, P., RochDI, A. \& DAVIS, A. 1992. Chemical basis of fluorescence alteration of crude oil and kerogen: 2. Fluorescence and infrared micro-spectrometric analysis of vitrinite and liptinide. Organic Geochemistry 18, 241-249. DOI 10.1016/0146-6380(92)90065-6

PŠENIČKA, J. 2005. Taxonomy of Pennsylvanian-Permian ferns from coal basins in the Czech Republic and Canada. 183 pp. Partially published Ph.D. thesis, Faculty of Science, Charles University, Prague, Czech Republic.

PŠENIČKA, J., ZODROW, E.L., MASTALERZ, M. \& BEK, J. 2005. Functional groups of fossil marattialeans: chemotaxonomic implications for Pennsylvanian tree ferns and pteridophylls. International Journal of Coal Geology 61, 259-280.

DO1 10.1016/j.coal.2004.10.001

SMITH, B.C. 1996. Fundamentals of Fourier transform infrared spectroscopy. 202 pp. CRC Press, London.

SOLOMON, E.P., BERG, L.R. \& MARTIN, D.W. 2005. Biology, $7^{\text {th }}$ ed. 1108 pp. Thompson Brooks/Cole, USA.

STERNBERG, K.M. von 1820-1838. Versuch einer geognostischen botanischen Darstellung der Flora der Vorwelt. Vol. II, 7/8, 81-200 pp. Gottlieb Hasse Söhne, Prague.

TRYON, R. 1976. Revision of the genus Cyathea. Contribution from the Gray Herbarium 206, 19-101.

ZODROW, E.L. \& CLEAL, C.J. 1988. Structure of the Carboniferous pteridosperms frond Neuropteris ovata Hoffmann. Palaeontographica, Abteilung B 208, 105-124.

Zodrow, E.L. \& MASTALERZ, M. 2001. Chemotaxonomy for naturally macerated tree-fern cuticles (Medullosales and Marattiales), Carboniferous Sydney and Mabou Sub-Basins, Nova Scotia, Canada. International Journal of Coal Geology 47, 255-275. DOI 10.1016/S0166-5162(01)00045-3

ZODROW, E.L. \& MASTALERZ, M. 2007. Functional groups in a single pteridosperm species: Variability and circumscription (Pennsylvanian, Nova Scotia, Canada). International Journal of Coal Geology 70, 313-324.

DOI 10.1016/j.coal.2006.06.010

ZoDrow, E.L., D'Angelo, J.A., MAstalerz, M. \& KeEFe, D. 2009. Compression-cuticle relationship of seed ferns: Insights from liquid-solid states FTIR (Late Palaeozoic-Early Mesozoic, Canada-Spain-Argentina). International Journal of Coal Geology 79, 61-73.

DOI 10.1016/j.coal.2009.06.001

ZODROW, E.L., MASTALERZ, M., WERnER-ZWANZIGER, U. \& D'ANGELO, J.A. 2010. Medullosalean fusain trunk from the roof rocks of a coal seam: Insight from FTIR and NMR (Pennsylvanian Sydney Coalfield, Canada). International Journal of Coal Geology 82, 116-124.

DOI 10.1016/j.coal.2010.02.006 